Portland State University

PDXScholar

$11-25-2019$

\title{
Lyrically Informed Performance: a Creative Study of Desire and Motivation in Rodgers and Hammerstein's Musical Collaborations
}

Fiona Palazzi

Portland State University

Follow this and additional works at: https://pdxscholar.library.pdx.edu/honorstheses

Let us know how access to this document benefits you.

\section{Recommended Citation}

Palazzi, Fiona, "Lyrically Informed Performance: a Creative Study of Desire and Motivation in Rodgers and Hammerstein's Musical Collaborations" (2019). University Honors Theses. Paper 807.

https://doi.org/10.15760/honors.825

This Thesis is brought to you for free and open access. It has been accepted for inclusion in University Honors Theses by an authorized administrator of PDXScholar. Please contact us if we can make this document more accessible: pdxscholar@pdx.edu. 


\title{
Lyrically Informed Performance: A Creative Study of Desire and Motivation in Rodgers and Hammerstein's Musical Collaborations
}

By

Fiona Palazzi

An undergraduate honors thesis submitted in partial fulfillment of the requirements of the degree of Bachelor of Arts

In

University Honors

And

Arts and Letters: Emphasis in Theater and English

\author{
Thesis Adviser \\ Jonathan Walker, Ph.D.
}

Portland State University 


\section{Introduction}

The names "Rodgers and Hammerstein" carry tremendous weight within America's community of theater artists. For those unversed in the icons of this specific community, Richard Rodgers and Oscar Hammerstein are a composer and lyricist duo who arguably created the most memorialized and influential musicals ever to have graced the American stage. Their characters are so thoughtfully written and alive that they appear to be jumping out of the pages of the score before one's very eyes. There is a unique intensity in the motivations and desires that these characters radiate through their songs. The expression of desire and motivation in the songs makes each character on stage vulnerable and deeply human to the audience. In the creative thesis, I investigate how I can use evidence of desire and motivation in Hammerstein's lyrics to inform my own acting and vocal choices when performing his characters' songs. For the purposes of this project, I will define "desire" as "a diffuse, continuous force that gets channeled into (or displaced onto) the constitution and expression" of one's object of desire (Cameron and Kulick, 2003). This definition of desire gets at the idea that each song serves a purpose within the play, which is to propel the story and characters forward in pursuit of that which they desire. The characters in each song need a reason to act, and this reason is rooted in their desires. The characters desire something, their desire motivates them to take steps towards getting that something, and we see these actions take place in the characters' songs.

These songs are the emblems of the Golden Age of musical theater. In fact, Rodgers and Hammerstein's music defined the Golden Age of musical theater, which is a stylistic era that occupied Broadway from 1943-1959. This era paralleled the hope of American audiences emerging out of the horrors of World War II. America was recovering from the aftermath and trauma of war in the middle years of the Golden Age period. Broadway became host to an 
assembly of troubled characters and dark plots, but it also held onto themes of solidarity and resilience. In the later years of the Golden Age, musicals began to introduce charged topics such as cross-cultural assimilation, which foreshadowed the political movements that came to the forefront of American history in the 1960s. All of Rodgers and Hammerstein's Broadway blockbusters-Oklahoma!, Carousel, South Pacific, The King and I, and The Sound of Musicmodeled these trends and received mixed reactions for their provocative subject matter.

Aside from providing a theatrical view of subject matter which conservative America had deemed too uncomfortable or irrelevant to address in public discourse, these revolutionary musicals were also constructed in an innovative way. The King and I, Oklahoma!, Carousel, South Pacific, and The Sound of Music — the musicals from which I have selected songs—are all products of Hammerstein's musical adaptations of non-musical plays, plays that relied solely on dialogue to represent the relationships and emotional dimensions of the characters. This root in purely dialogical narrative was partially what inspired the integrated quality in Rodgers and Hammerstein's "book musicals." The connection between song and dialogue is also where the critical component of my creative thesis comes into play.

I will be conducting a literary reading of the lyrics of each song on my set list: "Getting to Know You," "Surrey with the Fringe on Top," "Mr. Snow," "We Kiss in a Shadow," "Something Good," "I Cain't Say No," "When the Children are Asleep," "A Wonderful Guy," and "If I Loved You." For my literary readings, I will use a theory pertaining to "conversational storytelling" as a model for my method of analysis. The theory postulates that "anything that is incongruous with respect to social, cultural, or textual norms is potentially evaluative; incongruities (figures of speech, for example) serve as invitations to share the narrator's beliefs, ideas, attitudes, perceptions, or values" (qtd. in Labov and Polanyi, 1986). The sources I have 
collected in my bibliography contain crucial information about the historical period and cultural context in which these musicals were written and staged. These sources gave me a foundational knowledge of what features of the lyrics correspond with the norms of the time and the genre. This knowledge made social and contextual incongruities easier to recognize in the lyrics. Once I determined the incongruities in the lines of each of the songs, I was able to theorize about each of the character's desires and objectives in these songs. This knowledge helped inform the acting, blocking, and vocal choices I made when preparing my performance material and also helped me to create more focused and emotionally persuasive characters on stage.

In this creative thesis, I utilize an acting method rooted in the textual analysis of Oscar Hammerstein's song lyrics, which represent the characters' motivations and desires. These motivations and desires act as a point of contact between myself and the characters I will be portraying, and my analysis of them informed how I persuasively represent these characters in my recital. By first preparing the embodiment of a textual analysis of Hammerstein's characters, my performance will result in an entirely new text, which will be presented through voice, words, and movement. This text will open the door for further conversation of Hammerstein's work within the discourse community. In addition to writing essays that analyze the language of desire in these songs, I have conducted a physical experiment that explores how lyrics relating to motivation and desire can translate into vocal and acting choices in a live performance.

This paper is comprised of nine essays which analyze the lyrics of each of the songs I will be performing and an essay reflecting on how I used these analyses in the process of preparing my delivery of the songs. For all ten essays I have used a specific structure with the purpose of extracting how the characters use their lyrics, consciously or unconsciously, to allude to their underlying desire. I answer the questions: What is the character saying in each line? How 
are they saying it? And how does this hint at this character's desire? I have organized the ten essays chronologically, as this will be my performance order. 


\section{"I Cain’t Say No"}

The song "I Cain't Say No" is from Rodgers and Hammerstein's first musical together, Oklahoma! This song is sung by one of the supporting characters named Ado Annie, a farmer's daughter who has recently emerged from her pubescent shell. She sings this song as a response to her friend Laurey chiding her for pursuing more than one man at once. "I Cain't Say No" is Annie's explanation of why she can't help herself from doing so. This song provides the audience with evidence of Annie's desire for freedom and adventure. We see her try to rid herself of the guilt she feels for acting outside of societal norms.

At the outset of this song, Annie sets up her defense by establishing her credibility. She tells her friend Laurey how she has known "whut's right and wrong since [she's] been 10," which is Annie's attempt to make her following argument appeal to Laurey, who is strait-laced and sees many things as black and white. She follows this initial statement by informing Laurey about the stories that she has been told that warn her to stay away from men. Annie uses this information in order to separate her own behavior from behavior that is produced from a place of naivety.

These statements indicate Annie's desire for freedom and adventure because she uses them as antithesis for the argument she is about to make. She begins the song by stating that she is proper and aware that women should stay away from men. This adds emphasis to her later argument that her forward behavior is justified and that she shouldn't have to avoid male attention.

Annie goes on to express how she knows the rules when it comes to romantic behavior, but she wants to acknowledge that it's much more enjoyable to break them. Annie says this by presenting examples where she is expected to act one particular way, but finds herself 
responding with her own instincts instead and not regretting it. She describes a situation where she was supposed to slap someone who had tried to kiss her, but she "somehow, sorta, want[s] to kiss him back." She explains how her authentic self is not "prissy and quaint," and that she's "not the type that c'n faint." These statements frame her as the victim of these urges rather than the perpetrator of them.

These statements in which she describes her gut response to certain situations hint at her desire for freedom and adventure because in every example that she provides to Laurey the behavior that is expected of her is uninteresting and constrictive. She is highlighting how unfair she feels these social rules are that restrict her and shame her for doing what she wants.

In the next section of the song, Annie says that all women can deny that they don't desire adventure and freedom, but this denial is a lie. She says this by inviting Laurey to step into a potential scenario with her. She asks Laurey what she would do if she was given compliments such as being told that her lips were like "cherries, roses, or berries."

This invitation hints at Annie's desire for freedom and adventure because putting Laurey in her shoes is an attempt at making Laurey agree with her. When more than one person has the same viewpoints and desires, they are more socially acceptable to act on and express them. Annie is trying to recruit Laurey over to the side of unrepressed opinions and urges. She finishes the song by providing an image of a man in a "sombrero and chaps," describing him as a "Romeo" and openly admitting her attraction to him. By the end of the song, Annie has let go of all inhibition and has gotten over her original shame about her adventures with the cowboys she has met.

In this song, we see Annie attempt to present herself as educated and mature. She then admits that sometimes she acts outside of the social norms with actions led by her own instincts. 
She asks Laurey to step into her shoes, then Annie openly declares the desires she was

previously ashamed of. The song uses her encounters with the cowboys in town as a way to show us her adventurous, bold nature. I look forward to exploring the extremity of her lively character and her transformation from embarrassed to proud. 


\section{"Surrey with the Fringe on Top"}

The song "Surrey with the Fringe on Top" is a famous tune from Rodgers and Hammerstein's musical Oklahoma! In this song, Curly—a young cowboy—has waited until the last minute to ask a young woman named Laurey to the "box social." She is irritated at how long he has waited and is now resistant to the idea of going with him. He describes the Surrey (a horse drawn buggy) he intends to take her in, in an attempt to persuade her to say yes.

Curly begins the song with the bold phrase "when I take you out tonight with me." He is saying that he intends on taking Laurey to the dance with him, even if her initial answer is no. He says this by purposely speaking in statements rather than inquiries that would require Laurey's answer. His assumption that Laurey will say yes to his proposition is one example of his yearning yet innocent arrogance, which creates an incongruity in this song. His opening statement instantly sets up the rest of the song to be describing the dreamed-of scenario, not acknowledging that it has not yet happened or even been agreed to by Laurey.

Curly tells Laurey that he believes she wants to go to the dance with him by dropping subtle hints to her in the form of repeated phrases and questions. The phrases in this particular song are repeated in different forms, such as changing, "I'm a-thinkin"” to "you're a-thinkin," and the following line, “don't you wishty'd go on forever?" being said three times in a row. Curly subtly changes the pronoun "I" to "you" as a way of telling Laurey that they both want the same thing whether she admits it or not, which is to go to the dance together. Another form of repetition in this song is when Curly adds descriptive passages around the repeated word "surrey," to make it more alluring. An example of this is when the line "that shiny, little surrey," is repeated twice and then enhanced by the phrase "with the fringe on top." All these lines bring 
focus back to the vehicle they will supposedly share when riding to the box social. This surrey is not only a source of confidence for Curly, because of its glamour, but it is also a way for him to try to get what he wants, while not really saying it. He makes the idea of going to the dance together alluring by focusing on the glamour of their mode of transportation rather than proving himself worthy. He wants to spend the evening with Laurey, but by making it about the surrey he hides his own vulnerability. He is not asking her to go with him, he's asking her to go with the surrey. Perhaps when Curly says "the surrey with the fringe on top" he is unconsciously alluding to himself. He reveals a lack of complete confidence by framing it like the surrey will be taking her out.

Curly accidentally reveals to Laurey how thrilled he is at the idea of going to the dance with her by adding more and more detail to his proposition. He begins his phrase, restarts it, then adds more detail before finishing it. An example of this is located in the line "When I take you out in the surrey, when I take you out in the surrey with the fringe on top." It is as if Curly falters and has to regather his thoughts halfway through, revealing his excitement at such an idea.

Aside from the repetition in the lyrics, the alliteration in this song works to indicate Curly's mood and desire in each verse. The alliteration uncovers moments of Curly's intense feelings through audibly pleasing diction and other poetic qualities that contrast with the teasing, boastful nature of the song. Some examples of this include "fly in a flurry," "dogs'll dance," "wind'll whistle," "cows...in the clover," and "river will ripple."

Curly goes on to reassure Laurey that she will enjoy herself if she goes to the dance with him. As seen in these examples of alliteration, descriptions of many different animals are included throughout the song. Animals establish a physical and familiar setting, which is part of 
Curly's persuasive tactic. This tactic is to make the scenario of Laurey going to the dance with him a comfortable reality through his detailed description of the prospective evening in the song. Images of "horses," "chicks," "ducks," "geese," "cats," "dogs," "birds," "frogs," “toads," "cows," and a "lark" all infuse the song with a vibrant, bustling image of a spring evening. These descriptive details hint at Curly's joy around the idea of taking Laurey to the dance.

Curly's overwhelming hope that this evening will occur is shown through the thoroughness of his construction of the imagined evening. This image of a spring evening is carefully constructed through a subtly rotating viewpoint. The world slowly fills in, beginning with the distant idea of only the surrey and the horses pulling it and then including their whole surrounding — perhaps suggesting that Curly sees more possibilities with her than just an evening out. He combines the image of him and Laurey riding in the surrey with the image of the exterior of the surrey, and then the animals and nature that move around them as they ride together. Nature surrounds them and almost seems like another companion on their journey through Curly's use of personification. An example of this personification is when Curly quotes the words of the river. Not only does Curly advocate for himself in the song, he uses the voice of the river to agree with him, which asks Laurey “don't you wisht'yd go on forever and you'd never stop in that shiny, little surrey with the fringe on the top?"

Nearing the end of the song, Curly completes the description of this imagined future moment by describing how the sky above them will look. The final two stanzas zoom in to a more intimate and close up description of only Laurey and Curly alone, but almost shyly he describes Laurey in third person, as if he has floated off into his own personal daydream and has forgotten the present moment because the vision of the future is so vivid. Onomatopoeias are also utilized in this section of the song to make the moment even more real as he hushes a Lark 
that he imagines would be singing in that moment and hears the "kerplop" of Laurey's head landing on his shoulder. In the final line, he uses second person narrative to address Laurey again, but instead of describing anything new he acknowledges the beauty of his daydream by urging Laurey to slow down and take in the moment, saying "don't you hurry with the surrey with the fringe on the top."

These changes in viewpoint are particularly significant because they are carefully divided by verse (stanza). The separation of the verses is an incongruity in itself because there is a literal beat of separation before the character links the verse he has just sung to a new verse presenting a new point of view. The moment between each verse is a short pause in the story, used as a brief transition from idea to idea.

Curly's desire to take Laurey to the dance carries this song along from image to image of them observing the world form Curly's surrey. Curly confidently but carefully describes in detail a universe which is dependent on Laurey saying yes to his proposition. He is carried away by the loveliness of his own daydream and forgets himself for a moment as he pictures Laurey resting her head on his shoulder as they ride home together. He finishes the song by acknowledging the delightful nature of this image and asking Laurey to acknowledge it as well.

After uncovering these patterns in the lyrics, I look forward to exploring the idea that Curly's objective in this song is to describe the scenario he desires in such a way that Laurey has no option but to agree to this becoming reality. He uses each stanza to color the image of the future in a specific way, describing the animals, the sky, the water, the surrey until even he is consumed and overcome by the vividness of the picture he has painted. 


\section{"Mister Snow"}

The song "Mister Snow" is from Rodgers and Hammerstein's second musical together, Carousel. This song is sung by the character Carrie Pipperidge, who is a mill worker and friend to the female lead of the musical, Julie Jordan. In this song Carrie hears of Julie's budding romance with Billy Bigelow and decides to reveal her own engagement to Enoch Snow, a local fisherman.

Carrie's desire to marry Mister Snow is suggested by her vividly imagined dream of their wedding day. This song functions as the audience's first glimpse at Carrie's personal life and aspirations. Before this we only hear her comment on Julie, other characters, and events that Julie and herself have experienced together.

Carrie begins "Mister Snow" by making clear the deep admiration she feels for Enoch, whom she believes to be entirely deserving of it. Carrie verbalizes this admiration by describing the hard work Enoch puts into his job as a fisherman. She presents him almost as a product that she is marketing to Julie, bragging about how he comes home with a full load of fish "every night in his round bottom boat," expecting Julie to be impressed by this fact just like she herself is. Carrie's pride in Enoch's devotion to his career hints at her desire to marry him by making it clear she is aware that his financial stability makes him eligible to support and take care of another person as well. In other words, he is in an economically respectable position to marry.

When the main verse of the song begins Carrie admits how excited she is for her wedding day to arrive. She expresses this excitement by depicting this day in detail, playing it out with all of her different senses. She hears the bees and the birds, she smells the breeze, she sees the "cottage by the sea" they will move into, and she feels the "salty breezes" on her face. By feeling the wedding day through sight, sound, smell, and touch, Carrie's desire to marry Mister Snow 
becomes clear to Julie and the audience. Carrie is so eager for the day to arrive that she creates a simulated version of this day through her own imagination, which she can enjoy until the actual day arrives.

The concluding section of the song begins when Carrie describes kissing Mister Snow in front of their new "cottage by the sea." She finally reflects inward, focusing on her feelings instead of on this daydream of the future, Mister Snow, the proposal, and so on. In this section she tells Julie how she truly loves Mister Snow. She does this by both outright saying, "for I love that Mister Snow" and by describing Mister Snow with different terms of endearment: "young seafaring, bold and daring, bigbee whiskered, overbearing, darling Mister Snow."

This expression of love and tenderness indicates Carrie's desire to marry Mister Snow by revealing to Julie and the audience how all-encompassing Carrie's love is. By including both negative and positive connotations of Mister Snow in her terms of endearment, we see how she loves him unconditionally. She calls him "overbearing" and "darling" in the same line. In the context of Mister Snow proposing she expresses only positive feelings for him and the idea of marrying him, giving the audience no reason to believe she objects. His proposal unlocks an entire poetic description of Carrie's envisioned future with him, showing us how much joy she feels at the very idea of marrying him.

To pursue her own desire to marry Enoch, Carrie shares the news of her proposal with Julie. By telling a second person she can relive the joy of Enoch's proposal a second time. We see Carrie get lost in her own daydream about how beautiful that day and her future life will be with him. She acknowledges Enoch's desirable and undesirable traits and, in a way, begins to make her vows of commitment to him by expressing the acceptance and love of even the rougher parts of him. I look forward to exploring how she steps into the physical world of her wedding 
day and how she can interact with this imagined physical universe in order to reveal the depth of her joy to the audience. 


\section{"When the Children are Asleep"}

The song "When the Children are Asleep" is from Rodgers and Hammerstein's musical Carousel. In this duet, Carrie Pipperidge and her fiancé Enoch Snow sing to each other about the future they hope to have together. They imagine building a business, raising children, and then sitting in their living room after they have put the children to bed, enjoying each other's company and feeling grateful for the life they will have created.

In this song we become aware of Enoch's dreams to provide an ideal family life to Carrie as he describes his detailed plan of how he will financially support his future children and wife. The conventionality of his character adds a comedic element to the song. He is both sentimental and extremely practical, and one can see this through his parallel descriptions of his growing business and his growing family. He deeply desires Carrie's love and intends to build a safe home for her as a means of earning it. Carrie also desires Enoch's love, but she takes a less business-oriented approach, only singing along in the sentimental sections of the duet. This song functions as the audience's first look at Carrie and Enoch's one-on-one interactions. The song gives the audience an idea of why these two characters are so compatible. Before this, we do not really see how they complement each other since they had only interacted in the presence of other characters.

In the first stanza of the song, Enoch tells Carrie how he is a hard worker. He does this by using his current occupation sailing a "little boat" and owning a "little house" and singing that in a "manner of speaking [he's] doing very well." We see him recognize that although what he has is enough for most people, it is not enough for him and his future plans. He also confidently describes his engagement to Carrie, assuming she'll support his dreams for the future, saying how he "should be satisfied." This statement hints at Enoch's desire to deserve Carrie's love 
because he presents this statement almost as a supporting pillar to the dream he described earlier about wanting to do greater things with his life, both at work and at home. We can imagine that he wants to do greater things with his love for Carrie than just marrying her.

In the next stanza, Enoch boasts of his financially ambitious nature and his desire to possess a thriving business and a thriving family. He does this by laying out the chain of events that will expand his fishing business steadily, one boat at a time, echoed by him and Carrie expanding their family one child at a time. This intertwined idea of his business and family growing simultaneously again hints at Enoch's desire to earn and deserve Carrie's love by exposing his fervent belief that his family's life and happiness depends on his financial stability.

In the final stanza, Enoch softens, and takes a less economical stance on raising a family - perhaps remembering that Carrie's love is what supports his dream for the future. This is the verse in which Carrie joins in, as if she understands and is able to relate to what he is describing, this dream for a future full of family and love. He says that as he grows older he wants to be able to sit back and enjoy the beautiful life and family he has earned with her. He expresses this by suddenly switching his tone from bold and sure to gentle and sweet. Before he had used numbers to describe the children in the line "two little socks, three little socks." Now he uses more expressive language, imagining how he and Carrie will remember what "fun [they] have had, and be glad that it all came true." His words assume that later in his life with Carrie at his side, he will already have reached success, and in this stanza he no longer describes himself as trying to reach a particular goal; instead he depicts himself simply sitting and enjoying life with his partner. This change of tone again exposes Enoch's deep desire to deserve Carrie's love in ways that are not related to money or success at business. He no longer talks about finally securing his "Sardines" business or the number of rooms in his house. However, it is evident that 
he believes the only way to reach these moments of relaxation and enjoyment later in life will be through hard work and building a net of financial safety.

We see Enoch's strictness and softness. He first acknowledges his great ambitions as he imagines and describes his dreams of building his business and simultaneously his family. But then he loses his aggressive business mindset when he pictures his safe, sleeping children and his wife keeping him company.

I look forward to exploring the comedy and sweetness in this song with Zach, another actor and vocalist whom I will be bringing in to sing this duet with me. Both of these characters are a bit eccentric and this could manifest itself in the contrasting physicality and tonal qualities of our two portrayals of them. 


\section{"If I Loved You"}

The song "If I Loved You" is from Rodgers and Hammerstein's musical Carousel. In this song Julie Jordan, a young millworker, and Billy Bigelow, a barker at the local carousel, converse on the outskirts of town underneath a cluster of blooming cherry trees. Billy has just been fired from his job for defending Julie when his boss tried to kick her off the carousel. Julie has just lost her job for breaking the mill workers' curfew to stay out with Billy. Throughout this entire musical, Julie only desires to tell Billy that she loves him and to have Billy tell her the same. Julie understands that both she and Billy are not brave enough to face their emotions and vulnerabilities head on, so this song functions as a way for her to tell him how she feels in a method that is subtle enough not to scare him away or make her feel quite as vulnerable.

Julie begins the song by describing a scenario during her day in the mill. She uses this scenario indirectly to admit that her emotions towards Billy are bleeding into every other area of her life. During this day in the mill she is so distracted by her feelings that the thread she has years of experience working with at the mill gets tangled up in her hands "and the warp would get mixed with the woof." Framing this true statement as if it were hypothetical, Julie makes her first attempt to tell Billy how she feels. She does say that she loves him in every line, but purposely in ways that only she can understand. She is able to express her feelings without the fear of Billy knowing what she says is true.

In the first main verse of the song every line begins with the hypothetical "If," but the statements Julie makes grow closer and closer to a direct description of her behavior in the present moment with Billy. She first claims that "if" she loved him "time and again she would try to say," which is what she is attempting to do in that very line unbeknownst to him. Then she says that "if" she loved him "words wouldn't come in an easy way," which is a step closer to 
describing the behavior that Billy has actually observed in her. In the previous scene of the play Julie, her friend Carrie, and Billy are all standing in the woods together, but Carrie is the one responding to Billy when he speaks. Julie only says a word or two. Hammerstein builds a relationship between the audience and Julie in the line "words wouldn't come in an easy way" because we now know more about how Julie feels than Billy does. However, in the next line, Julie drops the hypothetical, "longing to tell you, but afraid and shy." This statement's relationship to the "if" she used in the previous line is purposely ambiguous to both Billy and the audience. She could possibly still be speaking in the hypothetical, but it can also be read as a stand-alone statement, in which case everything she has said so far is revealed to be real. With each line she sings, she gains more courage and takes a small step closer to expressing what she has desired all along to express: her love for Billy.

Julie continues her transition through imaginary and ambiguous descriptions of her feelings for Billy. Three lines after "longing to tell you," during which time she has still not made another use of the word "if," she tells Billy outright "how I love you," only to follow this immediately with the correction "if I loved you." This hypothetical statement juxtaposed by a statement that is obviously not hypothetical shows us Julie's literal struggle between not being able to deny her own feelings, but not understanding how to speak or act on them yet.

Julie's unconscious exclusion of the hypothetical "if" hints at her desire to admit her feelings to Billy by giving the audience and Billy a glance at what Julie feels when her guard is down as she states what she actually feels before she can think to censor it. This slip up both shows how, although seemingly shy and standoffish, Julie is hostage to her own adoration of Billy. In her quick retreat back into the hypothetical, we become aware of how frightened she is of her own emotions. 
To get a few steps closer to being able to admit her love for Billy, Julie describes situations that only she knows the meaning of and even tells Billy what she is thinking in the hypothetical in order to voice her feelings while avoiding vulnerability. By the end of the song she is overtaken by her emotional state and accidentally tells Billy "how [she] love[s]" him. She finishes the song with another hypothetical "If I loved you" in an attempt to retract her previous confession. I am excited to explore what words in the lyrics spur Julie accidentally to admit her true feelings at the end of the song. What are the different steps in her transition from selfconscious to being overtaken by emotion? 


\section{"Wonderful Guy"}

The song "Wonderful Guy" is from Rodgers and Hammerstein's musical South Pacific. Nelly, a young nurse, sings this song after an encounter with a Frenchman with whom she has fallen in love. Nelly's desire in this song is to rid herself from the embarrassment she feels for openly being in love. "Wonderful Guy" functions as her encouragement to herself and, ultimately, her full-out declaration of love and omission of self-consciousness. Nelly does not want to be shy about her feelings any longer.

Nelly begins the song by preparing herself for the outside world's response to her giddy, romantic feelings. She does this by visualizing her friends' reactions to her romance. She imagines how they will say she's "naive as a babe" to believe "fables" such as promised love from this man. She then visualizes her own defense being strong and steady, saying she will "loudly sing about flowers and spring." She ends this thought by planning her literal verbal retort to their condescending: "love is a grand and a beautiful thing."

This visualization of the future hints at Nelly's desire to be strong enough to be honest about her emotions by showing the audience her hope for her future self's strength. Similar to many other Rodgers and Hammerstein characters, she imagines her desired future in great detail in order to move one step closer to that reality.

Nelly goes on to say how happy she is about loving someone. Being in love makes her feel at home again. She expresses this by comparing her emotions to different occurrences and objects that remind her of her childhood in and around Little Rock, Arkansas. She describes herself as being "as corny as Kansas in August" and as "normal as blueberry pie." Both of these objects of comparison are seemingly unspectacular but hold special sentimental value to her. This sentimental value is particularly correlated with the giddy joy she experienced as a child. 
She illustrates how the man she has fallen in love with has made her feel the joy she had as a child with the line "no more a smart little girl with no heart, I have found me a wonderful guy."

This section of the song hints at Nelly's desire to rid herself of the need she feels to conform to social constraints by showing the audience that she acknowledges the uniqueness of the love she has found. This acknowledgement is justification for her open acceptance of her love.

Nelly finishes the song by saying how proud and happy she is to experience such emotions. She does this by correlating her current state of being to a "flag on the fourth of July." This ties her love to this idea of proud patriotism, which I'm sure was meant to strike a strong chord in the post-World War II-era. She furthers this idea by repeatedly proclaiming "I'm in love," in a sort of marching chant. She marches forward with her emotions as if she were leading her own victorious parade.

This zealous approach to declaring her love hints at her desire to free herself of embarrassment by showing her being overly bold and loud in order to compensate for her actual fear and shyness. By the end of the song, we see this simulated confidence replaced by the overwhelming joy of her real emotions. This switch occurs when the phrase "I'm in Love" is changed to "I'm in love with a wonderful guy!"

In Nelly's song "Wonderful Guy," we see her visualize the future in order to prepare herself to face criticism, then remind herself of how special and unique her love is. She then cheers herself on through a reference to patriotism and a chant that yes, in fact, she is in love. I am interested in exploring how Nelly slowly breaks down her barriers and has the unique ability to experience childlike joy even as an adult when influenced by the people she loves.

"Getting to Know You" 
The song "Getting to Know You” is from Rodgers and Hammerstein's musical The King and I. Ms. Anna is a British schoolteacher who has come to stay with the King of Siam as part of a cultural exchange. She teaches his children English and in this song she extends an offer of friendship after one of the children asks Ms. Anna if she likes her.

Ms. Anna begins the song by quoting an old adage, which states that a teacher learns from their pupils, then she changes to a much less formal tone and describes all the different ways she is learning about them and how much she is enjoying herself in the process. In this song we see Anna being honest about her emotions, a trait which is seen in other sections of the play as well. This honesty invites opportunity for vulnerability, connection, and friendship between herself and the mothers and children to whom she teaches English.

In the first two stanzas she implies that she is just as much of a student as her pupils are. She gets this message across by quoting an old lesson that was taught to her. By describing a scenario in which she is the student, she reinforces the message of the quote, that when "you become a teacher, by your pupils you'll be taught." This line hints at her desire to be friends with her students. She assimilates herself with them by reciting this line like a student reciting a lesson they learned. She is hinting that she and her students are learning together and are thus compatible.

In the next two stanzas she elaborates on her statement that she has now "become an expert on the subject [she likes] most. Getting to know [them].” Through her elaboration of what this statement means, she continues to push the idea that she and her students are equals by revealing emotions she experiences such as "hope" and enjoyment that are correlated with people of a younger age, people her students' age. She also uses the phrase "cup of tea" to subtly 
remind the children that they know about her and her British culture as well. She uses this line as an inside joke between her and her students because it is a reference to what they have learned together in her class. This elaboration hints at her desire for friendship and understanding between herself and her students by revealing that she has a young spirit, and she wants to make the children aware of these youthful parts of herself so that they can more easily relate to her.

Ms. Anna uses the last two stanzas of the song to express her gratitude towards her students for bringing her joy and making her feel "free and easy." She thanks her students by telling them of the positive effect their presence has had on her and explaining how it is due to "all the beautiful and new things [she's] learning about [them] day by day." This expression of gratitude works toward Ms. Anna's desire for friendship because friendship is situated on a basic level of respect, and Ms. Anna is establishing that she has that respect and admiration for what her students have given her

In the song "Getting to Know You," Ms. Anna pursues her desire to form a friendship between herself and her students by taking a less formal tone, assimilating herself to them, pointing out their common ground, and politely expressing gratitude at the positive effect they have had on her life and mood. I am excited to explore how Ms. Anna's character is both open and confident about the fondness she feels for the people around her. She does not seem embarrassed to express her moments of shyness and emotion. 
"We Kiss in a Shadow"

Rodgers and Hammerstein's "We Kiss in a Shadow" is a ballad sung by two young lovers, Tuptim and Lun Tha, in the musical The King and I. Tuptim is one of the king's junior wives and Lun Tha is the king's emissary. They meet secretly for fear of being discovered. The lovers describe how restricted their love is and acknowledge their shared desire for the freedom to express their love without being afraid of repercussions from the king. They go on to illustrate how they would act if this dream came to be.

The first section of the song, which describes how the lovers must conceal themselves, uses aspects of nature to suggest that hiding their love is unnatural and contrived. They depict themselves hiding "from the moon," which is the very emblem of romance. Then, in the following two lines, they describe their meetings, but without any figurative language whatsoever. They only say that their encounters are "few" and "over too soon." This stark way of speaking is an embodiment of how suppressed their own desires are. If these two lines were to be read alone, one might think the two lovers were merely strangers who happened to run into one another.

The message of their song gains a little boldness when they begin to speak of their collective desire for a different way of living, more specifically to "be free." This stanza is particularly relevant when it comes to unpacking the lovers' relationship to their own desires because of the line "alone in our secret," the secret being their love for one another. This line is a paradox, but also gets at the idea that their love is so strong that the two lovers are one being. Their love's secret existence separates them from the rest of the world. The next line of the stanza is "together we sigh," which not only implies physical synchronicity but also a mental and emotional synchronicity, because the sigh is a physical manifestation of their longing. 
In the song's final stanza, the lovers paint a picture of their dream and what their existence would be like if their desired reality came to be. The opening line of this stanza, "to kiss in the sunlight," is the first line of the song, "we kiss in a shadow," but reversed in connotation, creating a completely opposite yet parallel universe through the new structure of the sentence. The word "a shadow" becomes "the sunlight." Shadow and sunlight oppose each other in meaning and connotation, but the article change in these two phrases is an even more revealing marker of the lovers' hope. The change from "a," an indefinite article, to "the," a definite article, indicates that the lovers desire freedom so deeply that they cannot fathom a reality in which this dream does not come into existence. "The" is far more pointed and specific than "a," and "sunlight" is literally more illuminated than "shadow." With this image of the future, their jointly held hope builds. The diction of their words grow bolder through the alliteration in the line "and say to the sky." By the last line of the song, they proudly proclaim the very secret they have been trying to hide, "behold how my lover loves me."

In this song, we see the two lovers use each other as a sanctuary from reality. I look forward to exploring the idea that, to each lover, freedom and love are synonymous. Although in the context of this song the lovers are in hiding, there is something courageous in the specificity of their shared dream and the hope they are able to conjure from merely being with one another. 


\section{"Something Good"}

The ballad "Something Good" is from Rodgers and Hammerstein's musical The Sound of Music. The character who sings this song is Maria. The father of the family she is governess for is a heavily decorated Austrian Military Captain. Maria finds herself falling in love with him and this song occurs after he has just renounced his engagement to a Baroness and told Maria that he has loved her all along.

This song is unique because Maria does not desire anything more at this moment in the musical. She does not imagine the future, precisely because the love she has desired from the captain has already been given to her. This song functions as a way for the audience to understand Maria's sense of fulfillment and joy when she finally receives what she has been subconsciously pursuing throughout the entire musical.

In the first section of the song, Maria says that she is grateful and in awe of the fact that this moment in her life came to be. She says this by hypothesizing about what in her past caused her to deserve the present moment. She alludes to the love and presence of Captain von Trapp as being a blessing, something she has earned. This expression of gratitude is an indication that she is beginning to achieve her desires. She does not feel the need to focus on the future or a different state of being that she has yet to achieve.

After reflecting on what moments have led to the present, Maria vocalizes how she is aware that her current state of happiness is due to the companionship and love of another person, Captain von Trapp. She says this in the line "for here you are standing there loving me." In this line Maria finds beauty in the simplicity of the physical placement of Captain von Trapp "standing there loving [her]." She uses no figurative language to embellish this statement, which 
is indicative of the fact that she believes this simple occurrence does not need any embellishments to enhance its magnificence.

In the last section of the song Maria says that she knows that she has done something right to earn this moment of love, and this idea makes the love even more enjoyable. She says this by describing the love that is currently being exchanged between herself and Captain von Trapp in a mathematical sense, "nothing comes from nothing, nothing ever could." This use of the word "nothing" works in opposition to the concluding line of the song "somewhere in my youth or childhood I must have done something good." The word "nothing" next to the words "somewhere" and "something" create a juxtaposition. Hammerstein gives us the sense that Maria's life has gone from empty to full in this one moment of Captain von Trapp's confession of love. In addition to this contrast of "nothing" and "something," the structural balance of the phrase "nothing comes from nothing" indicates that she has achieved her desire to be loved by Captain von Trapp by giving the audience a feeling of completeness. The equation has been completed and life has come full circle to place her in this moment, a moment that fate and her heart have been moving her towards for the majority of the plot.

Maria reflects on the events of her past, embraces the present, and expresses her gratitude for simply standing next to her lover as a way of showing that she feels whole from achieving her desire: the love of Captain von Trapp.

I look forward to exploring how Maria's sense of inner peace can translate into a specific vocal tone and how this tone can be present throughout the entire song while not muting other emotions that are expressed. 


\section{Reflection}

In this reflection I will provide an overview of my findings about desire in each of the songs and briefly explain how I ended up using these findings in my rehearsal process. I will consider the steps of the preparation that went smoothly as well as the steps I would change if I were to do it again. Finally, I will assess what newfound knowledge and skills I gained from this project and what I am contributing to the discourse community through its completion.

In the song "I Cain't Say No" from the musical Oklahoma! Ado Annie desires to have the freedom to do what she wants. She compares her own behavior to the behavior society expects from her. She attempts to explain what she is going through to her friend Laurey. By the end of the song Annie has given up the hope of acting within social constraints. She embraces her own power and freedom. The lyrical analysis I wrote on "I Cain't Say No" informed my character choices by helping me pinpoint how Ado is trying to affect her scene partner, Laurey. I was able to locate some moments when Ado changes her language in order to appeal to what she believes Laurey's moral standards are. In rehearsal, I focused a lot on viewpoints and how different ideas live in different physical places off stage. For example, every time Ado references a man she looks off slightly stage right. I explored how Ado might interact with these different spaces so it is visually clear when she is addressing Laurey and when she is in her own daydreams. One discovery I made in rehearsal is that the midwestern dialect written into the song encourages a mixed sound, a style of singing that requires less space in the back of the throat and the soft palate in a lowered position. The dialect seemed to get me out of my head. It helped me veer away from a "pretty" sound when singing. "Pretty" is not a tonal quality that is useful in this type of comedic number. One difficulty I faced while preparing this number was applying the idea that Ado is trying to affect Laurey. I found myself feeling unaware of what Laurey's reactions 
were to my words as I went through the song. It was a challenge for me to make strong choices in the song regarding when I am speaking with earnestness versus when I am speaking with an agenda.

In the song "Surrey with the Fringe on Top" I found that Curly merely desires to spend time with Laurey. He uses a beautiful description of what their date together could be like in order to persuade Laurey to say yes. I applied my lyrical analysis while rehearsing this song by using all the descriptive words to help inform my blocking. In order for Curly to paint a persuasive picture he must fill it with details that both Laurey and he can relate to. Because she cannot see the images in his head, he must enact or at least allude to what those images are through his movement. I also focused on varying my tone in each verse to keep Curly's argument engaging. I tried to bring out words involving animals by imitating the sound each animal would make in my tonal quality. These sounds add an element of playfulness to the number, which is indicative of the nature of Curly and Laurey's courtship. What changed by the end of my rehearsal process is Curly's physicality. I had originally intended on playing him as a man but decided against it in the end. I found that trying to manipulate my physicality to depict a different gender took away from the earnestness of the number. Being able to manipulate my gender on stage is something I would like to work on for the future.

In the song "Mister Snow" I found that Carrie desires her wedding day to arrive. She creates an intricately detailed daydream of what the day will be like as a way to live it out repeatedly before it actually happens. I applied this idea in rehearsal by focusing on Carrie's relationship to Julie, the person she is speaking to in this song. I tried to imagine a close friend or relative as the person I was talking to in order to channel a comfortable sincerity that is only present when we talk to people we are very comfortable around. I discovered that if I could 
imagine Julie's reaction to what I tell her throughout the song, I am able to stay centered while also feeling excited to share the rest of my daydream with her. I found that it was difficult to balance expressing Carrie's love for Enoch with Carrie's excitement over the details of the wedding day. I had to search for ways I could always make it clear to the audience that she is excited about marrying because she is marrying him, not because of the celebration, beautiful church, or flowers she describes.

In the song "When the Children are Asleep" Enoch expresses his desire to be worthy of Carrie's love and Carrie expresses her desire live out a happy marriage with him. My duet partner Zach and I have worked on how Enoch's business-oriented mindset can manifest in his precise relationship to the rhythm and how this can contrast with Carrie's playful, awkward personality, which could manifest in her stretching the rhythm of particular lines. In the section of the song when Enoch and Carrie sing over each other, Zach and I worked on picking up on each other's dynamics to make it sound like a conversation. I discovered that by knowing clearly what my character's opinion is about the future or partner they sing about, the character's vocal traits become more distinct. I struggled to find a lighter sound while singing this song or as singers may know it, finding my pure head voice. The melody of the song covers such a wide range of notes that I really had to work on maintaining the same easy quality throughout my vocal range.

In the Song "If I Loved You" Julie and Billy desire to confess their love for one another, but neither of them are capable of opening up at such a deep level. Zach and I worked on adding in everyday moments of discomfort that would be familiar to the audience. In these moments Zach and my interactions feel forced and awkward. We discovered that these times of discomfort can have many different levels from annoyance to anger. Julie and Billy challenge each other. 
What proved difficult for Zach and me was the idea of letting go of a classical sound until the specific flashes of tenderness that require it. A classical sound throughout the entire song actually takes away from some of the moments of tension and discomfort between Julie and Billy that make their characters more believable.

In the song "Wonderful Guy" Nelly desires to express her love without embarrassment. I applied this idea in rehearsal by exploring her transition from serious to giddy. At the beginning of the song I tried to make her words feel more internal as she encourages herself to open up. By the end of the song, she lets the happy madness of her emotions out through movement, ridiculousness, and laughter. During rehearsal, I discovered that Nelly's character is significantly quirkier than I had previously thought. Her wordy phrases indicate that she is brainy and anxious. One aspect of the song that needed extra work was the transition from self-conscious to carefree. Letting out childlike energy took some getting used to as college students and all adults for that matter are often encouraged to be professional and composed. I have so much practice trying to be that "adult" person that it took some work to unlearn that way of presenting myself.

In the song "Getting to the Know You" Miss Anna desires a friendship and sense of understanding between herself and her students. I incorporated this idea into rehearsal by working on my physical presence and different ways I can make myself appear open and inviting. I discovered that I did not have physically to reach out in order to extend an offer of friendship, but rather consciously decide not to make myself smaller. This may seem like a basic action to take but it was a challenge considering that women in general are asked to take up less physical and social space than they naturally fill. This challenge was another instance in my rehearsal process where I had to unlearn the me I practice being in everyday life. 
In the song "We Kiss in a Shadow" Tup Tim desires to love Lun Tha without fear of repercussions from the king. I tied this idea into rehearsal by exploring how I can simulate the feeling of telling a secret. I practiced singing to small objects and visualizing fragile objects affected by the slightest brassiness in my voice. I discovered that the vowels of the second verse of the song encourage a more mixed sound (a type of singing that sounds less classical), which naturally contrasts with the tone I use while singing about the hidden parts of my love in the first verse. It was a challenge for me to switch my style of singing from classical to mixed while maintaining character traits that should be present throughout the song.

The song "I Have Confidence in Me" was written for The Sound of Music and was originally going to be on my set list. After taking another look at the sources I collected that had information on the construction of this musical I discovered that this song, although credited to Hammerstein, was written by Hammerstein's musical director, Vincent J. Donehue.

Hammerstein was very sick during the making of The Sound of Music and did not write as many of the lyrics as people give him credit for. Although I did not perform this song, I still learned from the process of analyzing its lyrics. In this song Maria desires the confidence to face the changes and challenges in her future. I applied this idea in rehearsal by working on every line that she repeats and how I can accentuate it differently each time I sing it. This vocal choice makes Maria's growing confidence throughout the song become clear. I discovered that tempo changes can also really help me to build up energy and power without having to increase my volume. I was tested by the length of this song. I had to think through the song and understand why I jump from one line to the next so I am able to remember the order of the lyrics in context.

In the song "Something Good" Maria has received her desire, Captain von Trapp's love. I studied this concept in rehearsal by searching for ways to accentuate her contentment and inner 
peace. I discovered that extra attention must be given to the placement of my feet during the song. My feet must be settled and my calves relaxed; otherwise, I cannot simulate any sort of feeling of contentment. Something that challenged me was keeping my eyes alive throughout this song. I noticed myself getting introspective, which is alright to a point, but I still need to be singing to another person even if they are not physically present during my performance. I must also take into consideration that I need to project outwardly towards the audience even if my thoughts are introspective.

I found that it was helpful to write these essays because it sparked new questions I had about the songs and gave me more of a general appreciation and understanding for how each of the characters' brains work. Even though I did not end up performing the song "I Have Confidence in Me," analyzing its lyrics still encouraged me to find new ways of approaching Maria's character. If I were to go back and change anything about my approach to the music, I would not just focus on the characters' desires outside of the song because focusing on desire alone seemed to make my acting choices a little more internal. It would have been helpful to spend more time analyzing how the character singing desires their lines to provoke a particular reaction from their scene partner. My research on desire mainly acted as background information to help me develop the characters by themselves, but it would have been helpful to analyze the text in a way that more directly gets to how each character acts when influenced by the reactions of the character they are speaking to.

The most valuable thing I have gained from this experience as a performer is practice with artistic integrity. I made my own character choices from my own analysis of the character choices rather than just imitating previously performed renditions of the songs. The practice of choosing whom I think these characters are and then believing in them enough to share them 
with an audience has helped me become more comfortable with committing to my vision of characters. 


\section{Bibliography}

Hughes, Diane, and Pauline Manley. "Expressing Artistic Development and Intent: Creative and Educational Pedagogy for Music Theater Studies.” 2010. Accessed April 21, 2019. https://researchers.mq.edu.au/en/publications/expressing-artistic-development-and-intentcreative-and-education.

This article makes the argument that to fully embody a performance piece, performers should explore the "development of pedagogical strategies." Professor Hughes and Professor Manley collected data from a group of university students that provide us with information on how different improvisational practices affect the student's depth of understanding for that piece's "intent," and how these practices are a pathway for "artistic development." The actor should construct their performance through a series of improvised explorations involving "movement and sound." The written text of the piece being performed is justified by the actor's performance, not vice versa. One of the authors, Diane Hughes, is a researcher and professor of Music and vocal Studies at Macquarie University in Sydney, Australia. She is the former National President of Teachers of Singing and her areas of specialty are vocal artistry, performance, and cultural musicology. The other author, Dr Pauline Manley, is the head of the Dance department at Macquarie University.

Kim H. Kowalke, “Theorizing the Golden Age Musical: Genre, Structure, Syntax," in A MusicTheoretical Matrix: Essays in honor of Allen Forte (Part V), ed. David Carson Berry, Gamut 6/2 (2013): 133-184.

This article outlines the formation of golden age musical theater; drawing from musicals preceding and proceeding this era in order to isolate the characteristics which make golden age 
musicals unique. The point is made that Rodgers and Hammerstein's work defined this era of musicals. Their work was a new (at the time) mixture of operetta and musical comedy, and took the name "musical play," because the music was so seamlessly integrated into the plotline. This article discusses the dramatic tension written into many golden age works as well as all of the subgenres of musicals being created due to the unique plotlines and themes being suddenly introduced on Broadway. The author, Kim H. Kowalke, received his undergraduate degree in Musicology at Macalester College, and his MA, MPhil, and PhD from Yale University. He teaches at Eastman School of Music as a Professor of Musicology, with his special areas of study in $19^{\text {th }}-20^{\text {th }}$ century music, opera, and musical theater: Hindemith, Orff, and Sondheim in particular. He is the founder of the "international Lotte Lenya Competition for theater singing." Taylor, Millie. "Experiencing Live Musical Theater Performance: La Cage Aux Folles and Priscilla, Queen of the Desert.” Popular Entertainment Studies. 2010. Accessed April 22, 2019. https://novaojs.newcastle.edu.au/ojs/index.php/pes/article/view/11.

This article uses La Cage Aux Folles and Priscilla, Queen of the Desert, as case studies to explain how emotions on the stage are transferred to audience members and then back to the stage again. When actors portray emotion through vocal articulation, physical presentation, and movement, the audience begins to feel empathy for them, due to the "mimetic response." The audience is experiencing a flash of "muscular memory of similar movements and the attached emotional states." The author, Millie Taylor, is a Professor of Musical Theater at the University of Winchester as well as a veteran director working with both nationally renowned Shakespeare companies and musical theater companies around Europe and the U.K. She has an MA in Theater Practice and a PhD in Drama and Music. Her areas of specialty are Musical Theater 
history, dramaturgy, performance analysis, and politics, pantomime, and contemporary musical theater.

Vipond, Douglas, Russell A. Hunt, James Jewett, and James A. Reither, "Making Sense of Reading.” Developing Discourse Practices in Adolescence and Adulthood, Ed. Richard Beach and Susan Hynds. Norwood: Ablex, 1990. 110-35.

This article outlines different "modes of reading." The mode depends on the type of narrative being analyzed, information-driven, story-driven, or point-driven. Information driven narrative is formulaic and calculated. It is most commonly used in math and science related texts. Story-driven narrative is focused on engulfing the reader in the world of the story. This sort of narrative is present in many books that are read for enjoyment. Many fiction and science fiction novels fall under this category. Point-driven narrative is correlated with "conversational storytelling," where the plot and depth of the characters unfolds itself through dialogue. Plays are a good example of this type of narrative. I will be using the point-driven model described in this article to examine the lyrics of the Rodgers and Hammerstein songs I will be performing. One of the authors of this article, Russel A. Hunt, is a Professor of English at St. Thomas University. I could not find sufficient information on the other authors of this article.

Cameron, Deborah, and Don Kulick. "Introduction: Language and Desire in Theory and Practice." Language \& Communication, vol. 23, no. 2, 2003, pp. 93-105.

This essay provides me with a definition for the term "desire," which I will be referencing throughout the body of my thesis. It discusses how desire is depicted in literary works. It also describes how desire is portrayed through the spoken word. One of the authors, Deborah Cameron, is a Professor of Language and communication at Worcester College at 
Oxford University. Her areas of expertise are sociolinguistics and linguistic anthropology. The second author, Don Kulick, is an Anthropology Professor at Uppsala University. He has also worked as a Professor of Anthropology at New York University. 